\title{
木造密集地域の共同建替えにおけるデザインコードについて DESIGN CODE SYSTEM FOR REBUILDING AREAS OF DENSE WOODEN STRUCTURES
}

\author{
織山和久*, 小滝 晃** \\ Kazuhisa ORIYAMA and Akira KOTAKI
}

\begin{abstract}
This study describes a method to develop an integral set of design codes by which small areas of dense wooden structures can be rebuilt to prevent wide spread fire caused by an earthquake and to establish a comfortable living environment and human-friendly townscape. In order to avoid problems of scalability and arbitrariness, we examined a methodology to formulate a design codes system, which places common-use alleys in the starting point, based on a psychological analysis, and focused on the syntactic side of the design code system. Prior experiment and application examples verified the effectiveness of a design code system with more efficient consensus building and use of space.
\end{abstract}

Keywords: areas of dense wooden structures, disaster control, design code, common-use space, alleys 木造密集地域,防災,デザインコード,コモンスペース,路地

\section{1. 研究の概要}

都区部直下型の地震発生に伴って市街地火災が多発し、木造密集 地域を中心に最大約 16,000 人、建物倒壊等と合わせ最大約 23,000 人もの人的被害、焼失棟数 42 万棟、倒壊と併せて 61 万棟もの建物 被害が想定されている1)。こうした震災被害の抑止には、木造密集 地域の街区内部を共同建替え注 1)で不燃化することが重要である注 2)。

これらの木造密集市街地の住民の多くは、街の雰囲気や環境、コ ミュニティを重視し、定住志向も高い注3)。子育て世帯を含む転入者 も、街の魅力を高く評価している 2)。街の将来像でも、低層建物が 連なる街並みで徒歩主体で暮らせることが望まれている注 4)。従って、 こうした街の魅力が確実に継承される共同建替え計画が提案された 場合は、より多くの住民の合意と参加が得られやすいであろう。

本研究は以上の問題認識の下に、木造密集地域における共同建替 えに際し、従来の街の魅力を育んできた諸要素を実現すべき環境条 件として明示した上で、それらを適える簡潔で明確なデザインコー ドに再構成寸る方法を考察した。そしてデザインコードの性能を模 型によるシミュレーション及び事例から検証する方法も示した注5)。

\section{2. デザインコードが実効性を有するための条件}

(1) 既往の研究成果による知見

これまでの研究成果からデザインコードは、(1)対象の範囲が広い、 (2)参照元が実在する、(3)専門家が関与する、といった条件において 効力を発揮してきたことが指摘される。

(1)対象範囲 デザインコードは、山・川・斜面・寺社等の都市景観 3)、棚田景観等のランドスケープ 4)、街区再開発 5)、沿道 6)など比較
的広域の範囲を対象とする巨視的な景観に適用事例が多い。背景に は、対象範囲が広域になるほど公共性が高まり、尊重する景観要素 も広く共有されるためにコード化されやすいとの事情があると考え られる。近年はより身近な範囲として、ポケット広場 7)、通り抜け 路 8)、横丁 9)などにも適用される例も見られる。

(2)参照元 デザインコードは、特に歴史的な街並みの保存に顕著な 成果を収めてきた。抽出された景観要素を生かし、門や蔵などの再 生等で町おこしにつなげた事例 10)、条例の制定、景観形成地区の指 定、補助金の交付等に制度化させた事例 11)12)も多く報告されている。 このように実在する景観要素から参照元を抽出・評価できれば、当 該地域の関係者間で合意が形成されやすいことが推測される。

(3)導出主体 デザインコードの統一性と多様性を両立させるために、 専門家が詳細仕様まで関与した事例も多い。パタン・ランゲージの 構築や発展 1314)、マスターアーキテクト方式によるマスターアーキ テクトとブロックアーキテクトとの解釈の調和 ${ }^{15)}$ 、住民・行政と協 働のワークショップ 16)17)等、関与のステージはさまざまであるが、 専門家の関与が有効に作用した実績は多い。

（2）木造密集地域の共同建替えにおけるデザインコード

しかしながら、木造密集地域の共同建替えにおいては、以上の三 条件は満足されにくい 18)。共同建替えは数区画と狭域かつ微視的で、 デザインの採択はともすれば個々人の意向に左右されやすい。木造 戸建てを耐火造集合住宅に建て替える以上、ファサードやボリュー ムなど既存の具体的な景観要素もそのまま継承することは困難であ る。また、木造密集地域は 2 万 ha、210 万世帯 ${ }^{19)}$ にも及ひ、これ らの全てに専門家が深く関与して、個別の地区・建物に至る詳細の
* (株)アキネット 代表取締役

** 国土交通省九州地方整備局 副局長
Chief Executive Officer, archinet,inc.

Vice Director-General, Kyushu Regional Development Bureau, Ministry of Land, Infrastructure, Transport and Tourism. 
デザインまで調整することは難しい。

以上の点を踏まえ、本研究では木造密集地域の共同建替えに適用 されるデザインコードについて、これを構成するための検討の起点 の設定、合意形成を促す客観的な根拠づけ、最小限で有効なコード 群の導出方法を検討した。さらに導出されたデザインコード群の有 用性を、シミュレーション及び実例から検証する方法を提示する。

\section{3. デザインコードの適用を通じて実現すべき環境条件の設定}

デザインコードの適用を通じて実現すべき環境条件の設定にあた り、検討の起点を、共同建替えで生じるコモンスペースとなる路地 空間に置いた。そして、既往の心理的側面の研究成果等を踏まえて、 路地空間が満たすべき客観的な環境条件を明らかにする。その上で、 コード群を簡潔で有効にするため、デザインコードの統語論（空間 の構成規則）的側面に焦点を当て、試案の具体化を試みた。

（1）コモンスペース（路地空間）への着目

デザインコードの具体化のための検討は、コモンスペースとして の路地空間を豊かにすることを起点に置いた。

その理由の第一には、居住者が、立ち話、子どもの遊び 20)、植栽 行為 21 等、コミュニティ形成の場としてコモンスペースの機能を重 視していることが指摘される。根津の将来像についてのアンケート 調査でもこうした機能を期待して、回答者の $36.1 \%$ から「現在の路 地空間を活かす」ことへ要望が寄せられている22)。

第二に、路地空間は、権利形態でも区分所有者全員の共有であり、 計画策定については区分所有者の合意が求められる。また竣工後の 維持管理も、区分所有者全員から成る管理組合が担うこととなる。 このように共有・共用される路地空間は、建替え前後の関係者の合 意形成や協働のあり方と深い相互関係にある注6)。

第三に、路地空間は、これを取り巻く建築の配置・形態・外観と 一体不可分であり、全体・各戸に生き生きとした住環境を生成する 大きな要素となる。路地空間のデザインは、その優劣が共同建替え 事業の成否を決定づけるほどに根本的で重要であると言える注7)。

(2) 路地空間に求められる環境条件

次に、こうした路地空間に求められる環境条件を、心理的側面の 研究等にもとづく客観的な根拠から導出する。

（i 路地の距離感：お互いに出会えば自然に会話がはじまり、支障 なくすれ違うために必要な距離感を、路地に確保する。

距離と会話可能性については、会話をしない者同士にとって、気 づまりを感じる会話域（約 $0.5 \sim 1.5 \mathrm{~m}$ )、他人同士でもいずれ接近し て話をはじめる近接域 $(1.5 \sim 3 \mathrm{~m})$ 、相手を知人と認め挨拶をかわす 相互認識域（3 20m）があり 23$)$ 、出会えば自然に会話がはじまるた めには路地幅員が近接域に対応したものであることが望ましい。

また、寸れ違い時に気にならない対人距離は、知り合い同士では $75 \mathrm{~cm}$ 前後、知らない者同士では $200 \mathrm{~cm}$ 前後、とお互いの親密度に よって変動する。この距離を保ってすれ違うとすれば、体幅 $50 \mathrm{~cm}$ 、 建物との距離 $30 \mathrm{~cm}$ としたとき、幅員は 235～360 cm となる ${ }^{24) \text { 注 8) }}$ なお、寸れ違い時の印象評価（中廊下におけるすれ違い）による と、幅員 $1.8 \mathrm{~m}$ から $2.1 \mathrm{~m}$ になると安心感や快適性は顕著に向上し、 $2.1 \mathrm{~m}$ と $2.4 \mathrm{~m}$ とでは印象に大差ないことが報告されている ${ }^{25)}$ 。 （ii）建物の圧迫感：路地空間の居心地が、両脇の建物による圧迫感 によって損なわれないようにする。建物から受ける圧迫感は、形態
率(視野の中に建築物が占める割合を壁面の立体角の割合で示寸值) 26) とアスペクト比（矩形の縦横比率）を物理指標とした関係式 圧迫感 $=2.41+2.197$ 形態率(対数 $)+1.667 \times$ アスペクト比(対数) から評価指標が得られること、この值が中位以下（7 段階評価の 4 以下）のとき建物の圧迫感は許容されることが知られている 27)。 (iii)立ち話 : 気兼衩なく立ち話しやすい場所が、路地空間に隣接し て配置されることが望まれる。人間の左右の視野角は $120^{\circ}$ が上限 であり、会話時にはこの範囲内で相手の表情をとらえられることが 条件になる。パーソナルスペース（人と人との快適距離）は、あま り恥ずかしがりでない人の場合で、知らない相手とは 1.0 1.2m、 親しい相手とは $0.6 \mathrm{~m}$ ほどで ${ }^{23)}$ 、話し相手が複数の場合でもこの距 離感は変わらない 28) 29)。また第三者の背中越しに話をしない。こう した前提で立ち話の最大人数を幾何学的に求めると、一辺 $0.6 \mathrm{~m}$ の 正六角形の頂点上に 6 人のメンバーが並ぶ位置関係が得られる注 9 )。 立ち話は当初は 2 人ほどから始まり、徐々にメンバーが追加・交 代しながら 6 人の輪が続くと想定されるが、後から来た人が立ち話 の輪に加わるには、六角形の半分は外から見えることが望ましい。 また他の人の通行を妨げないように、通路幅は $1.5 \mathrm{~m}$ 以上とる。さ らに話者の背後もパーソナルスペースとして $0.6 \mathrm{~m}$ の間隔をとる。

このような条件を満たす場合、立ち話のたまり場は幅員 $2.0 \mathrm{~m}$ 以 上の路地に接続した半径 $1.2 \mathrm{~m}$ ほどの半円状に囲われた形状になる。 (iv)遊び場：子どもたちは、自宅の周りの車一台がすれすれに通れ るくらいの幅員の路地を主な遊び場とし、低学年ほどその傾向が強 い30) そこではボール遊び、自転車乗り、なわとびなどに興じ、男 子はファミコン遊びも路地でする ${ }^{31}$ 。半屋外空間（屋根付きの外廊 下、庇の下など）における幼稚園坚の行動観察調查によると、そこ が奥行わずか $1.2 \mathrm{~m}$ でも鬼ごっこ・ペット遊びなどの「通過遊び」 や、ままごと、おしやべり、おもちゃ遊びなどの「滞留遊び」が発 生し、奥行が増すほどその頻度は高まる。また通過遊びは、他の園 児が室内と屋外との間を移動する際に、お互いに邪魔にならない場 所に多く生じる ${ }^{32)}$ 。以上から、子どもの遊び場として車一台分の幅 員の路地に半屋外空間が連続して配置されることが望まれる。

( v ) 植栽 : 密集市街地の住民たちは、身近な路地空間に鉢植えを置 いて生活に潤いを与え、その世話を通じてコミュニケーションを図 ることが報告されている ${ }^{33)}$ 34)。多くの場合、鉢植えは庇の下の外壁 前面から十数 $\mathrm{cm} \sim 1 \mathrm{~m}$ 程度離れた日照の良い箇所に置かれる。また 緑視率および緑視量を十分にとるには道路幅員 $2 \sim 4 \mathrm{~m}$ 程度が有効と される ${ }^{35)}$ 。このような植栽の場への配慮が望まれる。

(vi) 日照環境 : 路地空間における活動を快適にするために、適度な 日照を確保することが望まれる。これは、天空や路地から入射され る日照によって室内にも十分な明るさを保つことにもつながる。

読書に最適な光量は 500 ルクス、手芸・裁縫に最適な光量は 1,000 ルクス 36)なので、これに見合う自然光が路地から室内に導かれるも のとする。一方、路地の真夏のまぶしい日照（10万ルクス）は和ら げ、室内との間の明暗差による不快感を抑えることが望ましい。

日照を和らげるには路地に植樹を行って緑陰をとる方法が有力で あるが、こうした樹木にとっての良好な生育環境として、カシ、サ トウカエデ等の光飽和点 (10 千ルクス前後 $\left.{ }^{37}\right)$ ) に相当する光量を 路地でも確保するものとした。 
(vii)風環境：路地および室内に心地よい風が通ることを重視した。 夏季の日中平均気温 $25^{\circ} \mathrm{C}$ 以上での適風域は風速 $0.7 \mathrm{~m} /$ 秒以上、冬季 $5{ }^{\circ} \mathrm{C}$ 以下では風速 $1.3 \mathrm{~m} /$ 秒以下とされる ${ }^{38}$ )。東京（建蔽率 $50 \%$ ）で は有効空面積率注 10) $27 \%$ をとれば通風性能が良好となり 39 、夏の体 感温度も 7 9 ${ }^{\circ} \mathrm{C}$ 下げられる。さらに各住戸の開口方向を多くとるほ ど風通しは良くなり、南北通風の上に東西の空を開けて開口部を四 方向にとる場合は南空の中心風速は 5 割増になる 40$)$ とされる。

以上の検討を踏まえ、路地空間に求められる環境条件を表 1 のよ うに要約した。

\section{表 1 路地空間の環境条件}

\begin{tabular}{|c|c|c|c|}
\hline \multirow{2}{*}{ (i) } & \multirow{2}{*}{ 路地の距離感 } & 他人同士でもいずれ接近して話をはじめる近接域 & $1.5 \sim 3 \mathrm{~m}$ \\
\hline & & すれ違い時に気にならない幅員 & $2.35 \sim 3.6 \mathrm{~m}$ \\
\hline (ii) & 建物の圧迫感 & $\begin{aligned} \text { 圧迫感 }= & 2.41+2.197 \times \text { 形態率 (对数) } \\
& +1.667 \times \text { スメ゙ク比 (对数) }\end{aligned}$ & 4 以下 \\
\hline \multirow{2}{*}{ (iii) } & \multirow{2}{*}{ 立ち話 } & たまり場の半径 & $1.2 \mathrm{~m}$ \\
\hline & & 会話に加わりやすく、通過しやすい幅員 & $2.0 \mathrm{~m}$ 以上 \\
\hline \multirow{2}{*}{ (iv) } & \multirow{2}{*}{ 遊び場 } & 安心して遊べる路地幅員(車一台分) & $2 m$ 前後 \\
\hline & & 半屋外空間の奥行 & $1.2 \mathrm{~m}$ 以上 \\
\hline \multirow{2}{*}{ (v) } & \multirow{2}{*}{ 植裁 } & 外壁面からの距離 & $0.1 \sim 1 \mathrm{~m}$ \\
\hline & & 緑視率・緑視量が十分となる路地幅員 & $2 \sim 4 \mathrm{~m}$ \\
\hline \multirow{2}{*}{ (vi) } & \multirow{2}{*}{ 日照環境 } & 路地から室内に導かれる自然光の光量 & 1千ルクス \\
\hline & & 樹木の良好な生育に必要な光量 & $10 千 ル ク ス 以 上$ \\
\hline \multirow{3}{*}{ (vii) } & \multirow{3}{*}{ 風環境 } & 頁李·冬李の適風域の風速 & $0.7 \sim 1.3 \mathrm{~m} /$ 秒 \\
\hline & & 有効空面積率 & $27 \%$ 以上 \\
\hline & & 開口面 & 4 \\
\hline
\end{tabular}

\section{4. デザインコードの試案}

\section{(1) デザインコード試案}

路地空間の構成規則として、これに従うことで前節において導か れた 7 つ環境条件を満足するデザインコード試案を導出する。

具体化には、(1)設計および確認主体が事前に共通理解を得られる 明確で定量的な基準とする、(2)設計・確認の作業効率を確保するた めにコード数を最小限に抑える、(3)設計の自由度を保って創意工夫 を生かすためにコード群の積集合が過度に限定されない(図 1) 注 11)、 (4)デザインコードの適用が事業採算性を損なわない(経済性)、とい ったことが必要である。

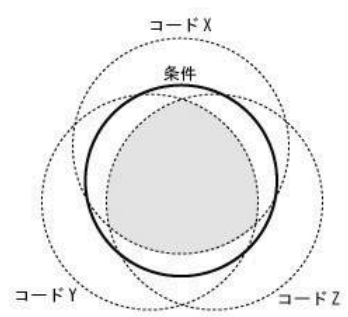

図 1 環境条件とデザインコード群

デザインコード試案は、上記（1)～(3)に沿って路地空間における「人 と人」「人と建物」の関係から具体化した。「人と人」については、 パーソナルスペースを考慮した通行とコミュニケーション、「人と建 物」では適度な囲われ感、明るさ感、涼風感を得るものとする。

(a)路地幅員 主出入り口が面する、幅 $2 \sim 3 \mathrm{~m}$ の天空通路を敷地内 に設けるものとする。

この路地幅員コードは、（i 路地の距離感の環境条件を適えるもの である。他人同士がいずれ接近して話をはじめる近接域（1.5m か ら $3 \mathrm{~m}$ ）にあると同時に、寸れ違いの際にも安心感と快適性を保つ 距離感（ $2.1 \mathrm{~m}$ 以上）をとるものとしている。このコードにより、
路地空間は、居住者同士でさりげなく挨拶して行き交う場になる。 また、この幅員は車一台すれすれに通るほどの空間であり、子ども たちの身近な(iv)遊びの場、大人が眺める $(\mathrm{v})$ 植栽の場にもなる。

(b)高さ 軒高は三層分 $10 \mathrm{~m}$ に抑える。

この高さコードは、形態率とアスペクト比に作用して、（ii)建物 の圧迫感を抑えるためのものである。

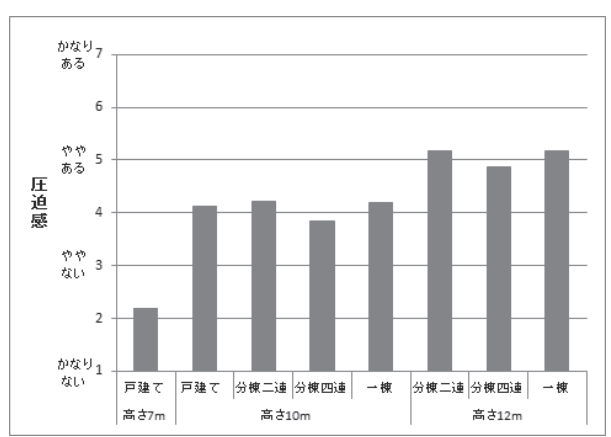

図 2 建て方別の圧迫感

戸建、分棟、一棟といった建て方別に一般的によく見られるモデ ル注 12 ）を設定し、圧迫感を数值化 ${ }^{27}$ )して比較した（図 2）注 13 ）。高 さ $10 \mathrm{~m}$ の場合、いずれの建て方でも数值は 4 前後にとどまり、圧 迫感を感じさせない。一方、高さ $12 \mathrm{~m}$ にした場合では、いずれの建 て方でも数值は 5 前後となり、圧迫感があることが示された。

(c)粒度 各住棟の規模は、縦横高さの三辺合計 $25 \mathrm{~m}$ 以下とする。 路地および室内に風や光を縦横から導くためのコードである注 ${ }^{14)}$ このコードによって各住棟の粒度を抑え、各階一戸分で二戸分にな らない誘導居住面積になり、開口部を四面にとりやすくする。(b) 高さコードによって高さを $10 \mathrm{~m}$ 以下に抑えても、路地沿いに建物壁 面が延々と続けば路地の通風・採光を妨げる恐れがあるが、このよ うな事態を避けるため、住棟の高さに応じて間口・奥行を制限する コードとして三辺合計式を採用し、合計值はその範囲内では住戸及 び路地に適風を導くように $25 \mathrm{~m}$ 以下と定めた。

高さを 3 層分 $(10 \mathrm{~m})$ として各階に $55 \mathrm{~m}^{2}$ （世帯人数 2 人の誘導 居住面積）を計画する場合、高さ $2.0 \mathrm{~m}$ 規格の引違い空（開口率は 1/2）を想定しつつ有効空面積 $27 \%$ 以上とするには、開口部面積 $14.85 \mathrm{~m}^{2}$ 、従って窓幅計 $14.9 \mathrm{~m}$ 以上が必要となる。最小周長でこの $55 \mathrm{~m}^{2}$ をとる矩形平面は一辺 $7.4 \mathrm{~m}$ の正方形になり、このとき空幅計 /周長計は $50 \%$ となるが、四面開口とすればこの空量は容易に確保で きる。この状態に対応する三辺合計值は $24.9 \mathrm{~m}$ となる。

また、高さを 2 層分 $(6 \mathrm{~m})$ として各階に $90 \mathrm{~m}^{2}$ （子供を含む世帯人 数 4 人の誘導居住面積注 $\left.{ }^{15}\right)$ ) を計画寸る場合、有効空面積 $27 \%$ 以上 とするには開口部面積 $24.3 \mathrm{~m}^{2}$ 、従って育幅計 $24.3 \mathrm{~m}$ 以上が必要と なる。最小周長で $90 \mathrm{~m}^{2}$ をるる矩形平面は一辺 $9.5 \mathrm{~m}$ の正方形であり、 この場合に空幅計/周長計は $64 \%$ 亿ぶが、四面開口であればこの分 量の空を配置できうる注16)。ここで同じ周長（縦横計 $19.0 \mathrm{~m}$ ）で奥 行 $4.5 \mathrm{~m}$ とすると間口 $14.5 \mathrm{~m}$ 、つまり路地沿いにこの長さの壁が続 くが、高さは 2 層分 $(6 \mathrm{~m})$ に抑えられるので通風・採光は補われる。 この状態に対応する三辺合計值は $25.0 \mathrm{~m}$ となる。

以上のような検討を踏まえ、階高を含めて設計の自由度を持たせ ながら、こうした範囲内で通風条件を適えられる明確で定量的な基 準として、縦横高さの三辺合計 $25 \mathrm{~m}$ 以内とするコード案を設定した。 
各階で二区画としても三面開口をとりやすく、これらの組み合わせ で、離れ、クロスメゾネットなども計画できるため居住者毎の多様 な暮らし方にも対応しうる。

この粒度コードと(a)路地幅員、(b)高さコードが相まった場合、計 画は低中層建物の分棟形式一誘導される。風洞実験によれば、 $4 \mathrm{~F}$ 中 層雁行配置または囲い込夕配置のときに外部空間に適風域の風がよ く起こる。一方、同等の容積率で戸建ての建込んだ街並みでは適風 域の風は全く起こらない。10F 高層配置、20F 超高層配置にすると、 強風も入り空を開放しにくい 41 )。この結果から低中層建物の分棟形 式が、(vii)風環境において優位となると考えられる。

こうして路地から室内一の通風も確保でき、夏でも空を開ければ 自然風で心地良く過ごせる風環境が得られる。また多方向に開口を 設けることで、太陽の動きとともに様々な角度から室内の各所に日 射・反射光が導かれ、(vi) 日照環境も向上できる。

(d)隣棟間隔 各住棟の間隔は $75 \mathrm{~cm}$ 以上とする。接続する場合には、 建物相互の接続面の面積割合が被接続面側の壁面積の 3 分の 1 を超 えないものとする。

建物と建物の間に一定の間隔をとって、適度な光と風を導き、居 住者が通行できるためのコードである。この(d)隣棟間隔コードによ って確保される隙間には、少なくとも 1 日 2 回は光が奥深くまで差 し込み、(vi)日照環境が改善される。ここに視線が通って路地に開 放感や活気が生まれ、挨拶から(iii)立ち話も始まる ${ }^{33)}$

（e）外壁明度 路地に面する建物外壁の色合いを明度 8 以上とす る。路地に面する建物外壁の明度は、路地の (vi) 日照環境を大きく 左右する。明度 8 のときの反射率は $58 \%$ に及ぶ $\left.{ }^{2} 2\right)$ 。暗い雨天の日の 光量は約 $10 \sim 15$ 千ルクスであるが 43)、明度 8 の外壁に 1 回反射し て路地に注げば約 6〜9千ルクスであり、十分な照度となる注 17 )。室 内についても、路地向かいの建物と自分の建物に 1 回ずつ反射して 室内に差し込むとすれば、暗い雨天の日でも光量は 3.4 5千ルクス となる。この(f)外壁明度コードと (a) 路地幅員、(b)高さ、(c)粒度、(d) 隣棟間隔コードを併せて適用寸れば、天空及び建物の隙間から入る 光が外壁に反射し、路地と室内に適度な日照がもたらされる。

(f)地上階の壁面部分後退（引き）一階部分のみ路地側から奥行 $1 \mathrm{~m}$ ・間口 $2 \mathrm{~m}$ 以上の一部壁面後退をとる。

この壁面部分後退コードは、まず（iii）立ち話のたまり場として半 径 $1.2 \mathrm{~m}(0.5 \sim 0.75 \mathrm{~m})$ の半円状の場所を路地に接続して設けるこ とが目的である (図 8,9参照)。この場は庇に覆われるので、日照の 厳しい時期や雨天時も、立ち話の時間内では不快にならずにすむ。

また、この路地に面して庇に覆われた場所は、奥行のある半屋外 空間として子どもたちの(iv)遊びの場として生かされる。大人にと っても鉢植えを並べる $(\mathrm{v})$ 植栽の場となる。この周囲に適宜樹木を 配置すれば（vi）日照環境、（vii)風環境をさらに改善できる。また 地上階の部分壁面後退を行っても、容積率に規定される延床面積を 上階で確保して総床面積を減らさずに計画できれば、土地利用にお いて不利性は生じない。

（2）デザインコードにおける統語論と語用論

以上のデザインコード群は、設計言語の統語論（空間構成の規則） に相当する。これらのわずか 6 個のコード群に従って計画すれば、 一定水準以上の環境条件を備えた分棟形式の低中層建築群が緩やか な統一性を保ちつつ成立しうる。内部の住戸計画も多様になる。基
準が明確で定量的であるため、条例化等も容易で行政判断の裁量性 もなく、膨大な共同建替え需要にも対応しやすい。

これらに加え、個別の地区・街区や区画ごとに、語用論（個々の 主体と場に応じた規則）としてのデザインコード群を付加すること も可能である。その項目としては、壁面線の後退位置、建築様式、 外壁や屋根・舖装の素材・色合い・割付、開口部の寸法・形状・位 置・仕様、外部照明や植栽の位置・種類等が挙げられる。具体的な 手法としては、これらを区画単位の設計指針、街区単位の建築協定、 広域の景観条例等に盛り込むことが有力と考えられる。

このように設計言語としてのデザインコードを、統語論と語用論 とに分けて規定することで、都市景観の広域の統一性と地区毎の多 様性を両立させて広範に展開することが可能となる。

\section{5. 検証}

以上のデザインコード試案の性能について、環境条件に関しては 模型によるシミュレーション分析、合意形成については事例分析に よって検証する方法を提示した。こうした分析により、コード群が 圥長性なく作用して望ましい環境条件が満足され、生成される建築 空間が経済性も有して合意形成に資する、といった点も確認される。

(1) 模型によるシミュレーション分析

ある区画を対象にデザインコードを適用した模型を作成し、環境 条件の変化や周囲への影響を検証する。これらの模型は、中野区南 台 2 丁目の木造密集地区を対象に、上記のデザインコード群を一部 または全部を適用した計画案を元にしている（図 3)。

現状では、隙間なく建て込み、主たる居住空間である一階の通風・ 採光等の環境条件は恵まれていない（図 4 )。

ここでコード(b)(d)(e)(f)を適用した場合には、中庭型の計画(図 5) が成立しうる。しかし、この中庭型モデルでは、通り抜けの路地と はならないために、寸れ違いで挨拶し、そこから立ち話が広がる、 といった効用は期待できないであろう。また周囲に対し、特に南側・ 西側の隣地居住者には、高さ $10 \mathrm{~m} ・$ 幅 $20 \mathrm{~m}$ の壁面が正対して、閉 塞感を与えるような形状となっている。

次にコード(a)を追加適用して路地を導入した結果、一棟路地型モ デル（図 6）が成立しうる。しかしこの計画でも南・西に高さ $10 \mathrm{~m}$ ・ 幅 $20 \mathrm{~m}$ の壁面が立ち上がり、周囲への閉塞感は解消されない。

さらにコード(c)を追加して全てのコードを適用した場合、低中層 建築物の分棟路地型の計画となる (図 7)。この分棟路地型モデルで は、壁面は分割されて閉塞感が和らぎ、通り抜けの路地空間がある ことで内外に視線や光・風が抜けて、周辺の建物規模とも調和した 建築空間が生成されることが伺える。

以上、模型による検証作業によって、4.1 で述べたようにデザイ ンコード群について、(1)明確で定量的な基準とする、(2)コード数を 最小限に抑える、(3)コード群の積集合が過度に限定しない、としな がら（ｉ）（vii)の環境条件を適えられることが確かめられる。

さらに、(4)事業採算性を損なわない点（経済性）もシミュレーシ ヨンから確認される。対象区画での建蔽・容積率の使用状況は、現 状は既存不適格建築物が多いために指定建蔽率 60\%に対し $79 \%$ だ が、二階建てのため指定容積率 $200 \%$ に対し使用容積率 $158 \%$ に留 まる。共同建替え後は、地上三階建で建蔽率 $60 \%$ 、容積率 $170 \%$ と 現状から土地利用効率も向上し、経済性も満足しうることが分かる。 
計画地概要

所在地

敷地面積

中野区南台

許容建蔽率

$438 \mathrm{~m}^{2}$

許容容積率

$60 \%$

$200 \%$
従前

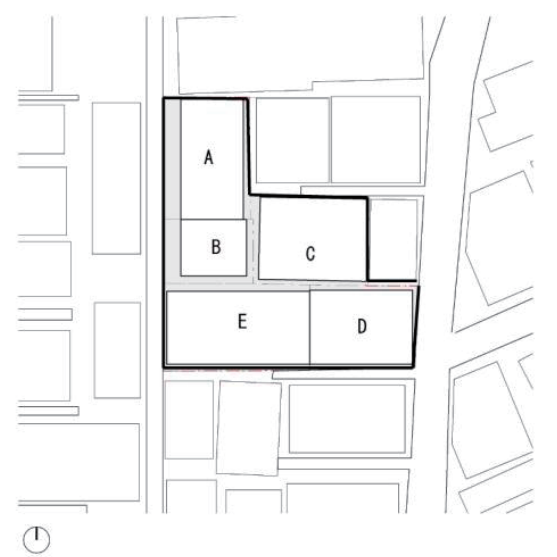

主体構造

木造家屋 5 棟

従前床面積計

従後
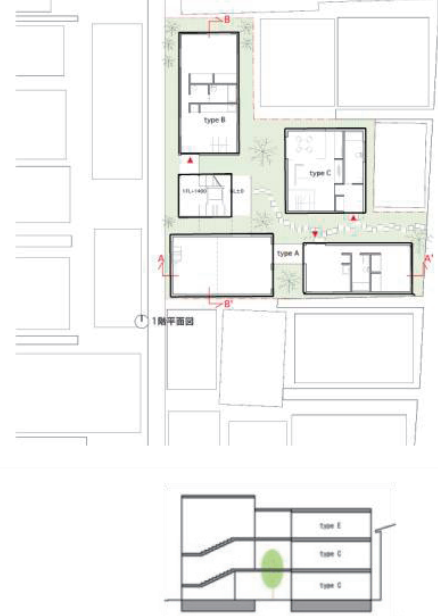

戸数

階数

主体構造

延床面積
（a）路地幅員
(b) 最高高さ
3. $0 \sim 4.2 \mathrm{~m}$
(c) 間口 $x$ 奥行 $x$ 高さ
10. $0 \mathrm{~m}$
5. $5 \times 9.4 \times 10.0 \mathrm{~m}$
$1.6 \mathrm{~m}$
(d) 隣棟間隔
(e) 明度（コンクリート打放し） 7.5
(f) 引き（奥行 x 間口） $1.8 \times 5.5 \mathrm{~m}$

図 3 中野区南台 共同建替え計画概要

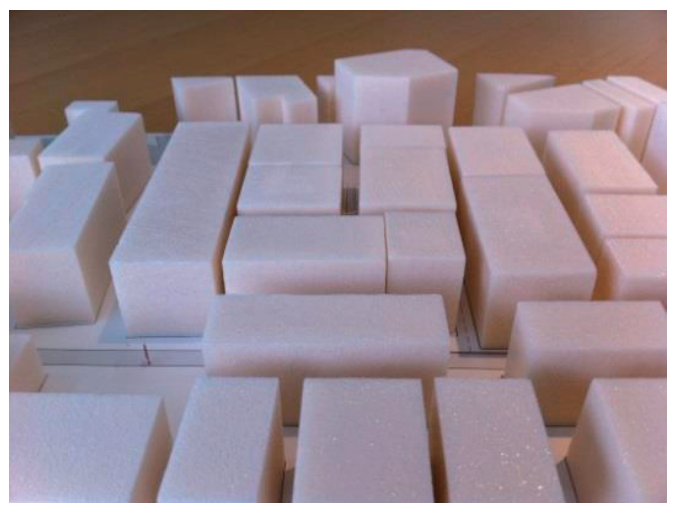

図 4 現状

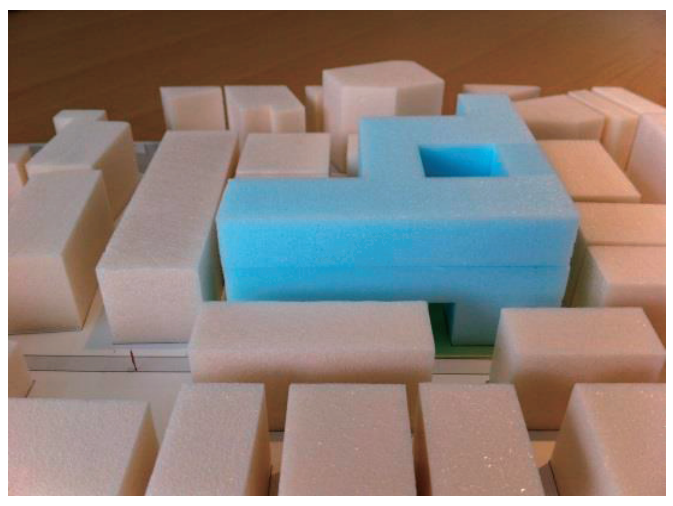

図 5 中庭型（適用コード $\quad b, d, e, f)$

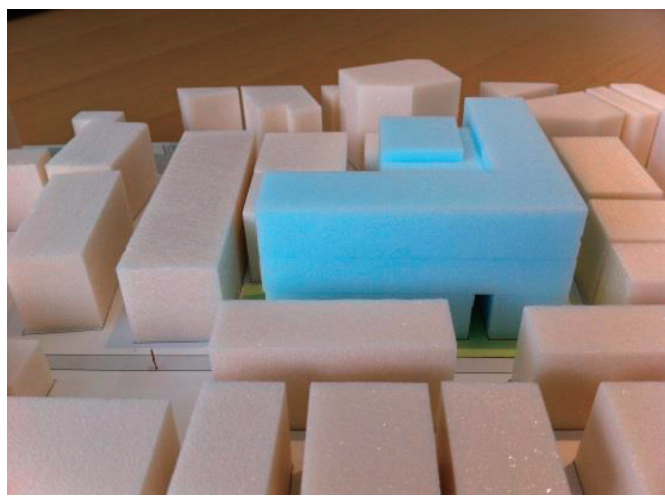

図 6 一棟路地型（適用コード $a, b, d, e, f ）$

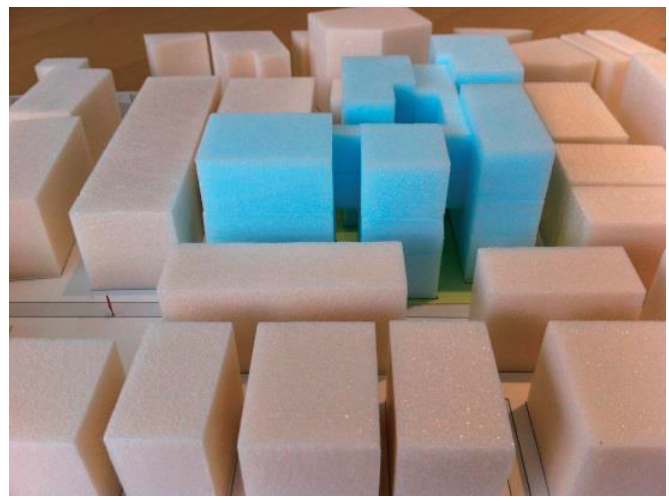

図 7 分棟路地型（適用コード $a, b, c, d, e, f$ ) 


\section{（2）実例による分析}

こうしたデザインコードが、共同建替えに至る合意形成を促し、 好ましい住環境を生成する効果について、実例によって確かめる。 いずれも図 8〜11のように、老朽木造家屋群のあった区画をコーポ ラティブ方式によって耐火造の集合住宅に建替えた例である。
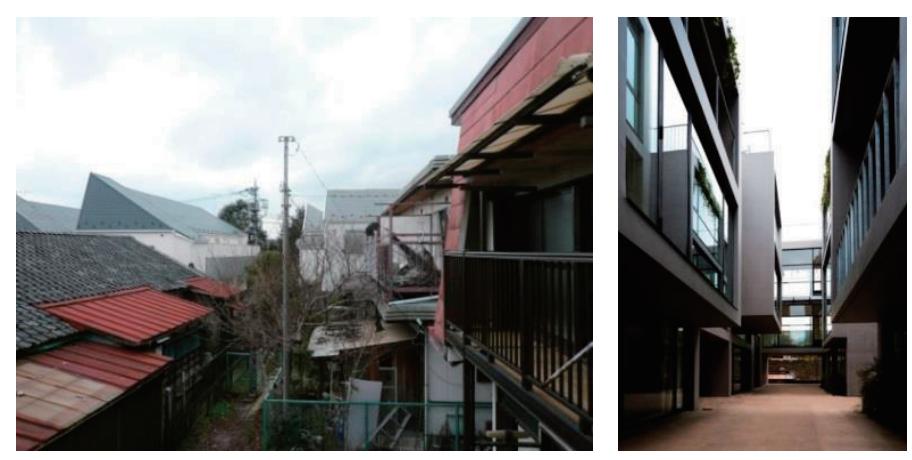

\section{図 8 建替え前後（中野区野方）}

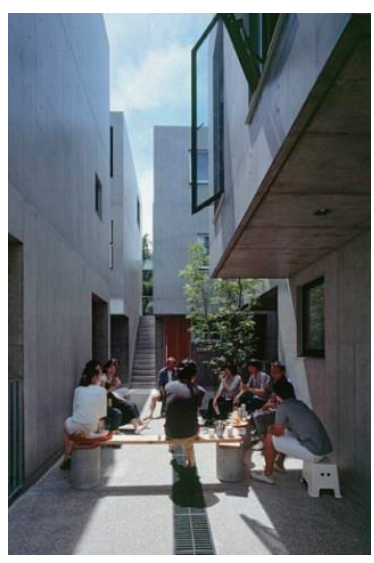

図 9 路地のたまり場と隙間 (目黒区八雲)

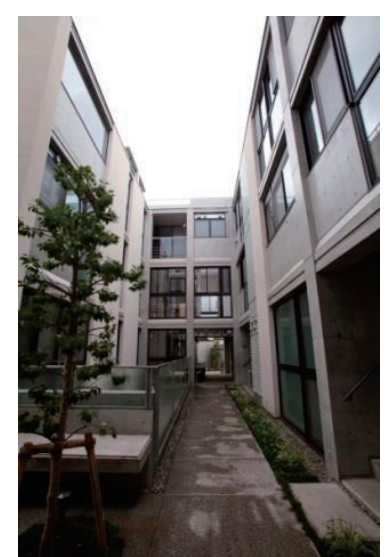

図 10 ベンチが接続する路地 (目黒区中根)
これらの実例では、統語論的なデザインコード群は暗黙のうちに 建築家に共有されて基本計画に反映された。このことは建築家が説 明した「路地を取り囲んで繫がる町屋のように住戸を配置した」44)

(図 8 右)、「(計画地が) 街区の（接道側でなく）真ん中にあるこ と。周囲の住宅と違和感なく同化し、できるだけ目立たない存在と するため中央に十字形にスリットを切り分節した。このスリットを 経路として 9 戸の住宅を積層し、それぞれの住戸に光と風がいきわ たるように配列している」45)（図 9）、『まち』と慗がる集合住宅の 路地。建物配置を『の』の字型とすることで、奥行と回遊性のある 変化に富んだ路地空間を形成している。…住戸間の独立性も持ちな がら繋がりも生み出し、通風・採光の確保にも寄与している」46) (図 10）といった設計指針に現れている。これらの事例では、居住予 定者は主に図面と模型を判断材料として住環境の魅力と経済性を評 価し、計画への参加を決定した。そして、外壁仕上げや植栽計画な どの語用論的なデザインコードは、自己居住予定者と建築家との数 回にわたる協議、ワークショップを経て決定された。

合意形成への効果を見るため、同時期に計画されたコーポラティ
ブハウス（17 棟）について、用地検討から入居予定者が確定して事 業着手に至る期間を比較した注 ${ }^{18)}$ 。この期間は、分棟路地型の計画 （4 棟）では平均 9 か月、一棟型の計画（13 棟）では平均 14 か月 であり、分棟路地型の計画では建替えに至る合意形成の期間が短縮 される傾向がみられた。

このように分棟路地型の計画が優位になる前提として、経済性に 優れた計画が導かれることにより、原地権者にとってより有利な土 地の買付条件を提示できるとの特性が存在すると考えられる。

さらに入居予定者には自由度が高く多様な計画案が好評で募集が 順調だったことが「在宅で仕事もできて空間が自由に使えそうだっ た（野方）」「離れがあって、面白そうだなと感じました（中根）」「よ くよく間取りを見ると、自分たちの生活に合っている (八雲)」47) というコメントから伺える。事業着手後も、路地空間について話し 合う中で共有意識が強まることが「植栽について話し合ったが、し っかりつくってしっかり管理している。年 1 回みんなで草取りして、 お花は自由に摘んで自宅に飾る (八雲)」「シンボルッリーやベンチ はすぐ全員で合意された (中根)」47) などの回答からも察せられる。

入居後には、いずれの路地空間も子どもの遊び場や大人の立ち話 の場として日常的に利用されることが、「ストリート（路地）は子供 の遊び場。(入居者の) ○○さんの結婚式場にもなった（野方）」「子 供が三輪車で一日中回っています (中根)」「出かける時間、帰る時 間が重なって、あいさつからちょっと話し込むことも多い。大きい 子たちはサッカーボールを蹴って遊んでいる（八雲）」47) といった コメントから確認される。

以上の実例分析から、路地空間を起点に分棟型を生成するデザイ ンコード群によって、事業着手に至る地権者および入居予定者の合 意形成が促される傾向が伺える。路地空間は、計画中には入居予定 者の共有意識を高め、入居後も遊び場や立ち話の場として利用され ている。これらの効果は、木造密集地域における共同建替えにも当 てはまる。土地条件は接道困難な数区画を統合した場合と実例とは 同様であり、建替え後も路地空間を介して街の魅力とコミュニティ が確かに継承されると予想されれば、関係者の合意形成が促される ものと考えられる。

\section{6. まとめ}

地震火災への対策には、木造密集地域の不燃化が重要である。 不燃化には共同建替えが効果的だが、この際に適切なデザインコ ードを適用することで、居心地の良い住環境や都市景観を合理的か つ広範に継承・形成し、関係者の合意形成を促すことができる。

本研究では、共有領域である路地空間を起点にとり、パーソナル スペースや圧迫感等の心理的側面の研究に基づく客観的な環境条件 を設定し、空間構成の規則に重点を置くことで、実効性を備えて合 意形成しやすいデザインコード群を導きだす方法論を導入した。以 上の方法論に従って、路地幅員、高さ、粒度、地上階の壁面部分後 退等の 6 つのデザインコードから成る試案を作成し、モデル及び実 例によってその作用を検証した。

この検証の結果、試案においても、住み心地や空間利用効率も向 上させつつ、魅力的な路地空間のある住環境や都市景観、さらにコ ミュニティを形成し、建替え事業に関して地権者および入居予定者 の合意形成を促しうることが確認された。 
計画地概要

$\begin{array}{lrll}\text { 所在地 } & \text { 中野区野方 } & \text { 目黒区八雲 } & \text { 目黒区中根 } \\ \text { 敷地面積 } & 796.59 \mathrm{~m}^{2} & 508.02 \mathrm{~m}^{2} & 662.51 \mathrm{~m}^{2} \\ \text { 許容建蔽率 } & 60 \% & 50 \% & 60 \% \\ \text { 許容容積率 } & 150 \% & 100 \% & 200 \%\end{array}$
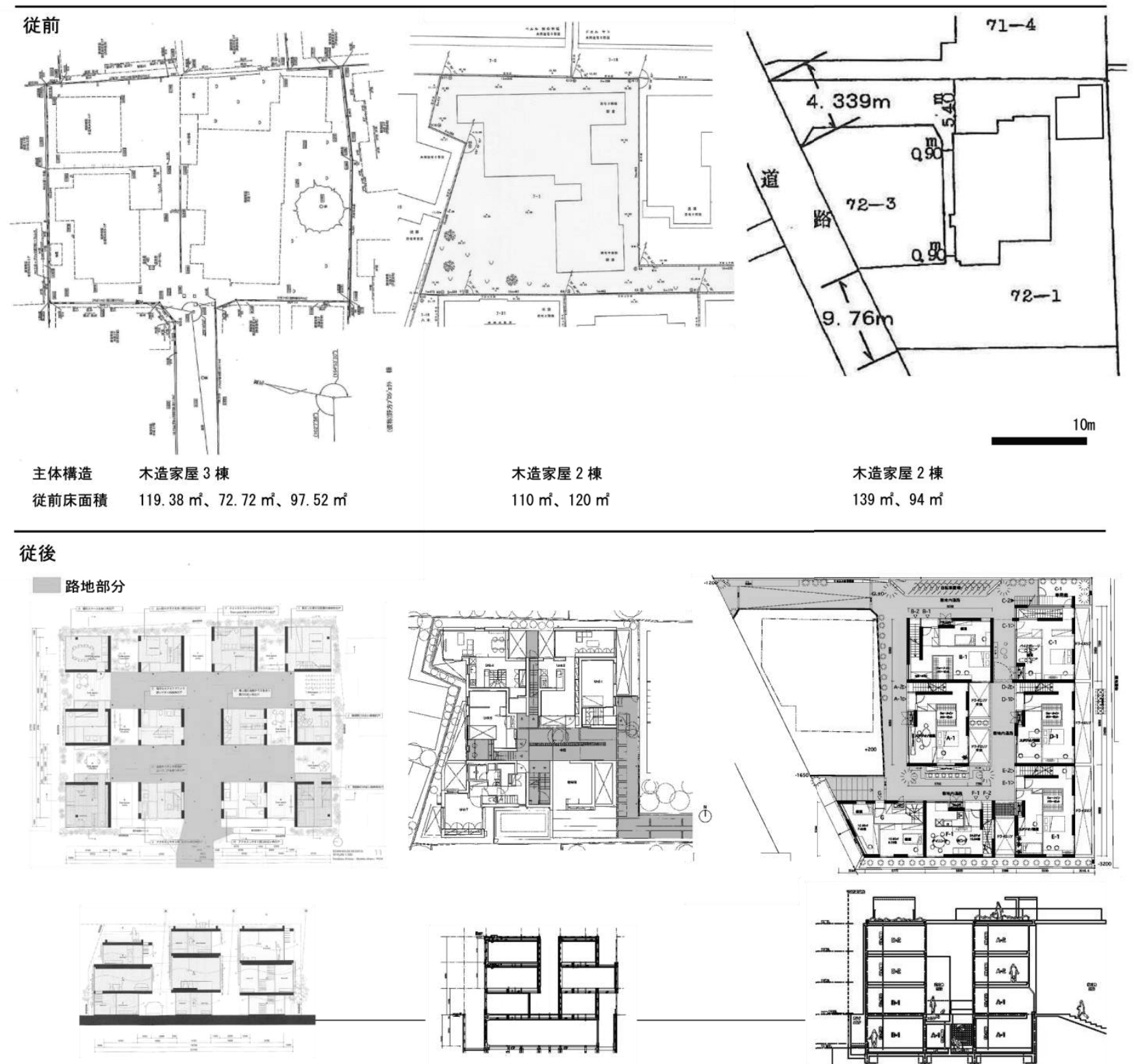

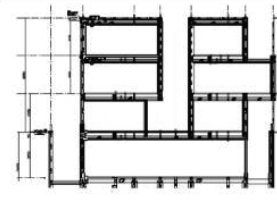

$-\infty$

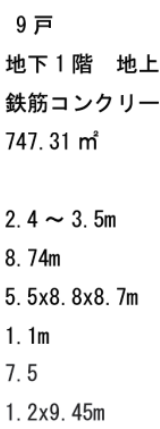

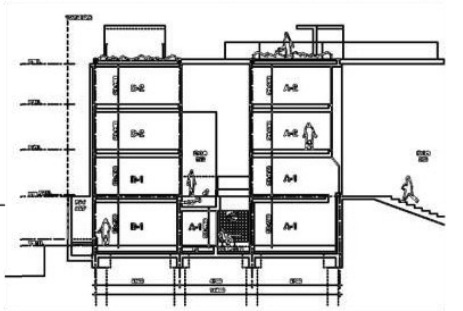

13 戸

地下 1 階地上 3 階

鉄筋コンクリート造

$1,301.71 \mathrm{~m}^{2}$

2. $3 \sim 2.7 \mathrm{~m}$

9. $95 \mathrm{~m}$

5. $5 \times 8.8 \times 10.7 \mathrm{~m}$

1. $18 \mathrm{~m}$

7. 5

1. $0 \times 2.2 \mathrm{~m}, 2.2 \times 6.0 \mathrm{~m}$

図 11 野方 $\cdot$ 中根 $\cdot$ 八雲の計画概要 
今後の研究の方向としては、こうしたデザインコード群に従って 木造密集地域を広範に不燃化するために、共同建替えの事業可能性 とその成立条件の検証、さらに地権者が自主的に共同建替えに参画 する仕組み、などに関する研究を進めたい。

\section{謝辞}

本研究に際し、垣内崇佳建築設計事務所のご協力を得ましたこと を記し感謝いたします。

\section{参考文献}

1）中央防災会議 首都直下地震対策検討ワーキンググループ: 首都直下地 震の被害想定と対策について (最終報告)，2013.12

2）葛野亮・後藤春彦・佐藤宏亮 : 都市更新期における下町一の転入者の生 活順応プロセス一東京都台東区根岸 4 丁目における転入者を対象とし て一, 日本都市計画学会都市計画論文集 vol. 46 No. 3, pp. 499-504, 2011,10

3）佐合美由紀・豊田洋一・佐藤圭二 : 景観エレメントの評価によるデザイ ンコードの要素一丘陵都市多治見市におけるケース・スタディ一, 日本 建築学会大会学術講演梗概集, F-1, pp. 1095-1096, 2004. 8

4）北澤大佑：景観管理におけるデザインコード活用に関する分析，2010 年度日本建築学会関東支部研究報告集 81 (II), pp. 307-310, 2011.3

5）森川禎二郎・武田友佑・佐々九雅也・阿部俊彦・真野洋介・佐藤滋 : 東 京の木造密集市街地における共同建替えを軸とした街区更新〜東京の 木造密集市街地におけるまちづくりの展開 3〜, 日本建築学会大会学術 講演梗概集，F-1，pp. 811-812，2002.6

6）飯島緑・真野洋介：密集市街地の住居外空間における領域形成に関する 研究，日本建築学会大会学術講演梗概集，F-1，pp. 65-66, 2008.7

7）森川禎二郎・武田友佑・佐々木雅也・阿部俊彦・真野洋介・佐藤滋 : 東 京の木造密集市街地における小規模事業の連鎖的整備〜東京の木造密 集市街地におけるまちづくりの展開 2〜, 日本建築学会大会学術講演梗 概集，F-1，pp. 809-810，2002.6

8）志摩陽一郎・真野洋介：密集市街地における既存細街路・空地を用いた 連続的歩行空間形成手法の研究, 日本建築学会大会学術講演梗概集, F-1, pp. 1125-1126, 2007.7

9）大村一仁 - 野村美里 ・渡邊享子・真野洋介 : 東日本大震災被災市街地に おける横丁の街並みデザインコードの検討一宮城県石巻市中心市街地 を対象として一, 日本建築学会大会学術講演梗概集, 2012, 都市計画, pp. 765-766, 2012.9

10）小林正美・古市修：まちづくりにおける「シャレットワークショプ」の 実験と評価に関する研究一岡山県高梁市における継続的ケーススタデ ィー一，日本建築学会技術報告集第 15 号，pp. 283-288，2002.6

11）畑山智彦・藤本信義・渡邊美代 : 民家を中心とする歴史的デザインコー ドの継承方法一居住者の生活変化に伴う民家・まちなみの歴史的デザイ ンコードの継承方法に関する研究 その 1 一, 日本建築学会大会学術講 演梗概集，E-2，pp. 487-488，2006.7

12）渡邊美代・藤本信義・畑山智彦：まちなみを中心にみた歴史的デザイン コードの継承方法一居住者の生活変化に伴う民家・まちなみの歴史的デ ザインコードの継承方法に関する研究 その 2 一, 日本建築学会大会学 術講演梗概集， E-2， pp. 489-490，2006.7

13） C. アレクザンダー : パタン・ランゲージ，鹿島出版会， 1984

14）五十嵐敬喜・野口和男・池上修一：美の条例, 学芸出版社, 1996

15）内井昭蔵 - 久間常生 $\cdot$ 川元明春 - 北嶋祥浩 $\cdot$ 内井理一郎 - 松田良 $\cdot$ 北尾 靖雅: 滋賀県立大学キャンパス設計におけるマスターアーキテクト方式 の報告一デザインコードの役割の考察一，日本建築学会技術報告集第 5 号, 1997.12

16）横井隆・古市修・小池博・小林正美：デザインコードによる都市景観整 備に関する研究一登戸区画整理地区における景観コントロールの実践 一, 日本建築学会大会学術講演梗概集，F-1，pp. 1093-1094， 2004.7

17）森川禎二郎・武田友佑・佐々木雅也・阿部俊彦・真野洋介・佐藤滋 : 東 京の木造密集市街地のまちづくりの課題の整理から見る今後の展望〜 東京の木造密集市街地におけるまちづくりの展開 1 , 日本建築学会大 会学術講演梗概集， F-1，pp. 807-808，2002.6
18）野田明宏・真野洋介・佐藤滋 : 木造密集市街地におけるデザインガイド の導出手法, 日本建築学会大会学術講演梗概集, F-1, pp. 1135-1136, 2005. 7

19）東京都：平成 9 年度 東京都住宅白書, 1998

20）小田啓文・齊藤広子・和田香織 : 戸建て住宅地のコミュニティ育成を目 指し工夫された道路空間の利用と評価〜道コモン型戸建て住宅地の居 住者の評価 その $1 \sim$, 日本建築学会大会学術講演梗概集, F-1, pp. 157-158, 2000.7

21）田尾美千瑠・福田由美子・稲田徹・栗崎真一郎：中庭を持つ集合住宅の 共用空間のコモンプレイス化に関する研究 その 1 , 日本建築学会大会 学術講演梗概集, E-2, pp. 221-222, 2008.7

22）文京区：根津駅周辺まちづくりアンケート調查，2006

23）西出和彦: 人間の心理・生態からの建築計画 (1)人人の間の距離，建 築士と実務 8(11)，オーム社，pp. 95-99，1985

24）齊藤ひとみ：コミュニケーション能力とパーソナルスペースの関連性, 愛知教育大学研究報告, 教育科学編 60, pp. 197-203, 2011.3.1

25）高久洋介・柳瀬亮太 : 建築空間における通路の形態と幅員に関する基礎 研究一印象評価実験による回避行動の検討, 日本建築学会計画系論文集 74, 638, pp. 809-814, 2009. 4

26）武井正昭他：圧迫感の計測に関する研究 $1 \sim 4$, 日本建築学会論文報告 集第 261 号，pp.105-114，1977. 11，第 262 号，pp. 103-113，1977.12， 第 263 号, pp. 71-80，1978.1，第 310 号，pp. 98-106，1981.12

27）黄泰然・吉澤望・宗方淳・平手小太郎 : 都市空間における一棟及び多棟 建物から受ける圧迫感に関する研究, 日本建築学会環境系論文集, 616 , pp. 25-30, 2007.6

28）高橋鷹志・高橋公子・初見学・西出和彦・荻谷哲郎：空間における人間 集合の研究 個人および集団の Personal Space その 1, 日本建築学会 関東支部研究報告書, 1980.3

29）高橋鷹志・高橋公子・初見学・西出和彦・苅谷哲郎：空間における人間 集合の研究 個人および集団の Personal Space その 2, 日本建築学会 関東支部研究報告書, 1980.3

30）吉永真理・横山明子・木下勇：まちでの遊びが子どもの生活リズムや心 身健康状態に及ぼす影響に関する研究, 学校保健研究 51, pp. 183-192, 2009

31） 中村攻・横山隆・宮崎元夫 : 都心における子供の遊び生活と遊び空間に 関する研究一東京都中央区・城東小学校区をケーススタディとして一, 千葉大園学報 第 39 号, pp. 53-59, 1987.3

32）張嬉卿・仙田満・井上寿・陽喜徴 : 幼稚園における半戸外空間に関する 研究, ランドスケープ研究 日本造園学会誌 66 (5), pp. 437-440, 2003.3

33）金栄㚒，高橋鷹志：密集住宅地の「住戸群」における路地と隙間の枠割 に関する研究, 日本建築学会計画系論文集 第 469 号, pp. 87-96, 1995.3

34） 小谷幸治・柳井重人・島田正文・勝野武彦・ 丸田頼一 : 東京都中央区に おける路地の緑の実態と住民意識に関する研究, 第 11 回環境情報科学 論文集, pp. 261-266，1997.10

35）篠塚香里・横張真・栗田英治・渡辺貴志 : 密集市街地における鉢植えの 緑の配置と形態，ランドスケープ研究Vol. 66 No. 5, pp. 825-828, 2002.3

36）日本工業標準調查会：照明基準総則（JIS Z 9110：2010），2010

37）宮地重遠, 村田吉男編：光合成と物質生産, 理工学社, 1980

38）村上周三、森川泰成: 気温の影響を考慮した風環境評価尺度に関する研 究〜日平均風速と日平均気温に基づく適風、非適風環境の設定, 日本建 築学会計画系論文報告集，第 358 号，pp. 9-17, 1985.12

39）赤林伸一・坂口淳: 戸建て住宅を対象とした通風性能評価手法に関する 研究一その 6 最小換気回数と有効空面積率に関寸る研究一, 平成 22 年度空気調和・衛生工学大会学術講演論文集 $3,2010.9$.

40）赤林伸一・村上周三・加藤信介・小林信行・服部孝博 : 住宅の通風に関 する実験的研究 その 1 実大の住宅モデルにおける測定, 日本建築学 会大会学術講演梗概集, 計画系 58, 環境工学, pp. 455-456, 1983.9

41）廣瀬雅恵・ 三浦昌生・持田灯・富永禎秀・松岡洋介：住戸配置パターン による風環境変化の風洞模型実験, 住宅地の住戸配置パターンと外部空 間の風通しに関する研究 その 2 , 日本建築学会大会学術講演梗概集, D-1, pp. 835-836, 1997.7

42）JIS Z 8721-1993 色の表示方法 三属性による表示

43）人工環境デザインハンドブック編集委員: 人工環境デザインハンドブッ ク, 丸善、2007

44）新建築 89(2) , 新建築社, pp. 89-95, 2014.2 
45) 新建築 $88(10)$, 新建築社, pp. 112-119, 2013.8

46) 新建築 $87(2)$, 新建築社, pp. 118-187, 20122

47）掲載事例 3 棟内の住戸に入居した計 10 名を対象としたインタビューコ メント, 2013-14

\section{注}

注1）東京都「木密地域不燃化 10 年プロジェクト」実施方針 (平成 24 年 1 月) でも、東京の最大の弱点である木密地域の改善に対し、延焼遮断帯の形 成よりも先に二大目標の第一として、市街地の不燃化を促進し、延焼に よる焼失ゼロの「燃えないまち」を実現、を掲げている。

注2）木造密集地域には、老朽木造家屋が接道困難敷地に建つ割合が高く、不 燃化には共同建替えが必要とされる。こうした接道困難敷地の分布状況 は、有田智一・岩田司「接道困難地の実態に対応した接道特例許可の運 用のあり方一中野区のケーススタディ一」日本建築学会計画系論文集 第 533 号、135-142、2000 年 7 月 などに詳しい。

注3）根津 1-2 丁目の居住者へのアンケートでも住環境評価の満足度は順に、 「交通について」 $61.3 \%$ 、「まちの雾囲気について」46.0\%、「買い物 について」 $36.0 \%$ 、「文化教養施設」 $30.1 \%$ 、と街自体に魅力を感じて いる。今後についても、「火災等への対策を期待する」（31.7\%）する とともに、「住み続けたい」 $76.1 \%$ と定住の意向は強い。その理由とし ては「通勤・買い物に便利」73.0\%、「地域に愛着がある」 $64.8 \%$ 、「周 辺の環境に満足」54.6\% と住環境を積極的に評価している（文京区「根 津まちづくりアンケート調査」平成 18 年)。定住意向については、荒 川区 $87.7 \%$ (荒川区「第 36 回区政世論調査」平成 24 年）、中野区 $78.4 \%$ （2011 年中野区区民意識・実態調査）と他の木造密集地域でも高率を示 している。ちなみに東京全体での定住意向は、76.2\%（東京都「都民生 活に関する世論調査」平成 24 年）、世田谷区 $83.1 \%$ （世田谷区「世田 谷区民意識調査 $2012 」$ 平成 24 年）、杉並区 $84.54 \%$ （杉並区「第 45 回 杉並区区民意向調査」平成 25 年）具体的な意見としては「火事は怖い けれど、ここは同じ世代や顔見知りが多くて住みやすい。」（産経新聞 2013 年 6 月 2 日）、「（マンション建設計画にも）延焼防止は見込め ても、住民は部屋に閉じこもり隣近所との交流が途絶えてしまうのでは」 （日本経済新聞 2013 年 6 月 11 日）などにみられる。

注4）根津の将来像についてのアンケート調査では、施設面において「歩行者 優先道路・買い物道路の整備」 $45.1 \%$ 、「下町情緒を残寸文化・歴史あ る建物の改修・保存」 $45.7 \%$ 。「現在の路地空間を活か寸」 $36.1 \%$ 、建 物面では「日照などに配慮してあまり高い建物を建てさせない」 $48.7 \%$ 、 「火災や地震に強い建物を建てる」38.2\%、が上位にならぶ。対照的に 「土地の有効活用のために中・高層化を進める」は、 $5.0 \%$ にどまる。

注5）このように密集市街地にふさわしいデザインコードが機能すれば、ケヴ イン・リンチが提起したように、パス、ディスリクトといったエレメン トが豊かになって都市環境のイメージアビリティを高め、人々に美しく 楽しい環境と大切な記憶の連続性をも保つだろう(ケヴィン・リンチ「都 市のイメージ」岩波書店、1968)

注6）この意義は「住まい手が関与して個人的な影響というものを互いに及ぼ しあうような街路の空間は、やがて彼ら自身のものとなり共有空間にな
っていくものだ。」（ヘルマン・ヘルツベルハー：都市と建築のパブリ ックスペース」鹿島出版会、1995）に端的に表現されている。

注7）東京都安全条例においては、長屋建てには幅員 $2 \mathrm{~m}$ 以上、共同住宅でも 出入口が前面道路に面していない場合は床面積 $300 \mathrm{~m}^{2}$ 超で幅員 $3 \mathrm{~m}$ 以上 の敷地内通路の設置を義務付けている。このように現行法規の下で共同 建替えを行う際には、一定規模以上の通路が敷地中心ないし端部に必ず 附置されることになる。

注8）近世以降の東京もこうした距離感が都市空間を構成し、江戸では表通り は幅員 3 5 間 (4.8 9.0m) に対し、生活道路である路地は 6 9 尺 (1.8 $\sim 2.7 \mathrm{~m})$ 程度であり、1938 年までは道路幅員の法定最低限度は 9 尺 ( $2.7 \mathrm{~m})$ と定められ、こうした幅員の道路が密集市街地の細街路として 今日も残っている (陣内秀信「東京の 空間人類学」筑摩書 房、1985）。

注9）立ち話がこの人数 で行われると、関心

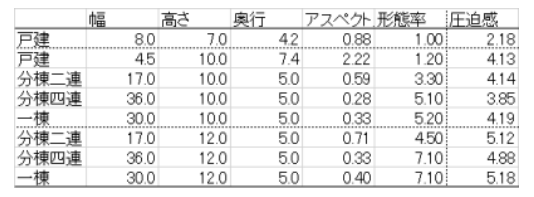
や話題に応じていろいろな組み合わせが出来て話も長く続きやすい。6 人の間での会話相手の組み合わせパターン数は、 6 人全員が 1 通り、 $4+2$ 人で 15 通り、 $3+3$ 人で 20 通り、 $2+2+2$ 人で 90 通り、で計 126 通りに もなる。ちなみにこれが 5 人では 11 通りに留まる。

注10)床面積に対する開口部の面積

注11）例えば、（vii）風環境の条件を満足させようとして、計画段階で熱流体 解析を用いた風環境シミュレーションを義務付けた場合は、微細な条件 設定の違いで結果は相当に左右され、解析のたびに費用もかかるのでこ れに応答しながらの計画修正を重ねることは現実的ではない。あるいは 室内の通風効果を得ようと、建物の間口寸法、奥行寸法、開口部位置の 個々に詳細なコードの積集合をとった場合では設計の自由度は失われ て、様々な敷地形状や入居予定者の多様な暮らし方に対応した柔軟な計 画は困難になる。

注12) 建て方は、戸建、分棟（二連、三連）、一棟のそれぞれについて、右表 のとおり、一般的によく見られるモデルを設定した。戸建では階段室を 含めて延床面積 $100 \mathrm{~m}^{2}$ とるものとし、分棟形式では粒度コードに合わ せて間口 $7.5 \mathrm{~m}$ 、住棟間の路地幅は $1 \mathrm{~m}$ としている。

注13)ここで想定している視点の位置は路地の中央であり、(a)の路地幅員コ ードを前提として建物から $1 \mathrm{~m}$ 離れた位置としている。

注14) 指定容積率 $150 \%$ 以上の東京の木造密集地域の建替えを前提としている ため、経済性の観点から平屋建ては想定外としている。

注15) 小中学生(うち 1 名は 10 歳未満)の子ども 2 人を含む 4 人世帯とした。 国土交通省「住生活基本計画（全国計画）」平成 23 年 3 月 15 日

注16) 南北通風の上に東西の空を開けて開口部を四方向にとる場合は南空の 中心風速は 5 割増になるので、必要な空面積はより少なくて済み、開口 部の位置に関して設計の自由度はより大きくなる。

注17)壁面が老朽木造家屋並みなこげ茶色の場合は、明度は 3、反射率は $6 \%$ に過ぎない

注18)いずれも、アーキネット事例（用地検討時期 2008-9）である。 


\section{DESIGN CODE SYSTEM FOR REBUILDING AREAS OF DENSE WOODEN STRUCTURES}

\section{Kazuhisa ORIYAMA* and Akira KOTAKI**}

* Chief Executive Officer, archinet,inc.

** Vice Director-General, Kyushu Regional Development Bureau, Ministry of Land, Infrastructure, Transport and Tourism.

The fireproofing of the wooden buildings in densely crowded areas is the most important measure to prevent widespread fire caused by an earthquake.

Cooperative rebuilding is effective for fireproofing. Moreover, it is an ideal opportunity to establish a far more comfortable living environment and human-friendly townscape by applying an appropriate design code system. Design code systems in Japan work in broad areas under public control, traditional townscapes filled with referential design elements, or in hands-on professional commitment to design details. On the other hand, it is not easy to formulate a design code system for cooperative rebuilding in densely areas because they are under private control, filled with few referential design elements, and suffer from a lack of professional hands to handle tens of thousands of rebuilding sites.

Under these circumstances, we examined a methodology to generate a practical and acceptable design code system by places the common alley space at the starting point, setting an objective environment condition based on psychological studies such as personal space and sensitivity to building pressure, and focusing on the syntactical side of the design code system. According to the methodology, we formulated a tentative design code system consisting of six codes, including alley width, a total of three sides, and an alcove, and then verified their effectiveness through the use of models and examples. This confirmed that the tentative design code system for attractive alley space could create a comfortable living environment, human-friendly townscape, and a community with more efficient use of space

In order to rebuild wooden buildings in dense areas on the design code system, a forthcoming survey will examine the feasibility of the cooperative rebuilding method and design mechanisms to encourage landowners to participate in rebuilding cooperatives. 